\title{
EQUiLIBRIUM
}

Quarterly Journal of Economics and Economic Policy

2014 VOLUME 9 ISSUE 4, December

p-ISSN 1689-765X, e-ISSN 2353-3293

www.economic-policy.pl

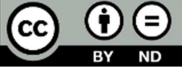

Lizińska, W., Marks-Bielska, R., \& Serocka, I. (2014). Operations Performed by Business Environment Institutions in the Process of Foreign Investment Acquisition: a Case Study of Investor Service Centres. Equilibrium. Quarterly Journal of Economics and Economic Policy, 9(3), pp. 65-78, DOI: http://dx.doi.org/10.12775/EQUIL.2014.025

Wiesława Lizińska, Renata Marks-Bielska, Izabela Serocka*

University of Warmia and Mazury in Olsztyn, Poland

\section{Operations Performed by Business Environment Institutions in the Process of Foreign Investment Acquisition: a Case Study of Investor Service Centres}

JEL Classification: $E 02 ; F 21 ; F 23$

Keywords: business environment institutions; foreign investment; investor service centres

\begin{abstract}
The quality of institutions is important for economic growth and inflow of foreign direct investment. Business environment institutions may introduce certain adaptations of the conditions as a response to foreign investors' expectations. The main objective of the research was to evaluate business environment institutions, exemplified herein by Investor Service Centres, in terms of their active participation in the process of attracting foreign investors. The empirical investigation (using questionnaire forms, carried out in the first half of 2013) was completed by employees of 10 centres (62.5\%). COI employees use most of the available sources of information about foreign investors. COIs are very active in their information search, and do not resort to the simplest possibilities, for example the Internet. Foreign investors contacted offices having previously found relevant information about chosen investment locations. COIs actively cooperate with other institutions in order to attract foreign investors. They undertake various activities to reach this aim, most of which demand a high degree of engagement. Most often COI employ-
\end{abstract}

(C) Copyright Institute of Economic Research \& Polish Economic Society Branch in Toruń Date of submission: May 29, 2014; date of acceptance: August 7, 2014

* Contact: wieslawa.lizinska@uwm.edu.pl, renatam@uwm.edu.pl, University of Warmia and Mazury in Olsztyn, ul. Oczapowskiego 4/202, 10-957 Olsztyn, Poland 
ees promoted available investment sites themselves rather than delegate this task to agencies. In order to improve the efficiency of COIs, they should strive towards building relationships between institutions.

\section{Introduction}

In economy, an increasing contribution to the influence on ongoing economic processes is attributed to individual institutions and institutional structures, which is currently emphasized in both theory and in empirical studies. The activity of particular importance of public governments policies and institutions occurs in attracting foreign investors because they are considered the most important in this process.

The main objective of the research was therefore to evaluate business environment institutions, exemplified herein by Investor Service Centres, in terms of their active participation in the process of attracting foreign investors.

As the main thesis of the paper it was assumed that despite the operation of the Investor Service Centres according to the standards of the Polish Information and Foreign Investment Agency, regional branches have different level of activity in the process of obtaining foreign investors. This activity was assessed in the area of: obtaining information, establishing cooperation and actions, with particular emphasis on promotional activities.

In connection to the above general goal and thesis, more specific aims were defined, such as:

- evaluation of the process of collecting information about investors by a COI versus the acquisition of information by investors about investment opportunities,

- identification of institutions with which COIs collaborate, as well as diagnosing and evaluating the areas of cooperation between the said institutions,

- evaluation of the role of activities pursued by COIs, especially promotional campaigns.

The main objective and specific aims of the study listed above were attained based on results of the author's own research. The empirical investigations consisted of a survey. Questionnaire forms were mailed to representatives (the heads of regional branches) of all (16) COIs. The survey was completed by employees of 10 centres $(62.5 \%)$. The survey contained a structured list of close-ended questions (with a suggested 'cafeteria' of answers), half-open questions and a matrix question with a single reply, which contained an evaluation scale for activities undertaken by a COI. The study was carried out in the first half of 2013. 
The article contains a brief characterization of the importance of institutional factors in the process of affecting foreign investors and discussion of the results with regard to direct research problems: acquisition of information about investors by COIs versus acquisition of information about investment opportunities by investors, diagnosis and assessment of areas of collaboration between investor service centres (COIs) and other institutions, activities undertaken by investor service centres while acquiring investors.

\section{Institutional factors affecting foreign direct investments}

The importance of institutions stems from the fact that more attention is paid to the role of institution in economy. Other reasons are the developing institutionalism and inclusion of concepts developed by the New Institutional Economy (NIE) into the mainstream economic thought, hence the growing popularity of interdisciplinary approaches in contemporary economic research (Miłaszewicz, 2011).

As supported by results of research carried out globally, the quality of institutions is a long-term decisive factor shaping the wealth of individual countries. The relationship between the quality of institutions and economic growth has been verified (higher quality institutions correlate with a faster real GDP increase rate, more efficient production means and a higher share of private investments) (Acemoglu et el., 2005; Lissowska, 2004; Zalesko, 2014). The institutional system is also the main determinant of entrepreneurship activity (Balcerzak \& Rogalska, 2010), while the study provided by Balcerzak (2011) confirms the existence of integration processes in relation to economic governance and institutional order.

The interest in the new institutional economics has increased during the crisis. To overcome the crisis and to prevent future crises it is essential to increase regulation at the national and supra-national levels and to foster institutional conditions of the development (Rudolf, 2012).

Institutional factors which in theoretical considerations describe the foreign direct investment (FDI) are perceived as the ones creating external conditions. Among these factors are the ones which pertain to characteristics of the environment in which a foreign company functions (Geldner, 1986; Rymarczyk, 1996). Institutional solutions are very important when taking decisions about the internalization of production, hence the quality of institutions becomes a significant investment factor (Williamson, 1998). 
For unlocking the growth potential of a region, it is essential that all institutions which create business environment promote entrepreneurship. The role of the institutional environment and the quality of public authorities as determinants of the regional development have been highlighted in theories of regional development (Lizińska, 2012).

Relationships between institutions and the inflow of direct foreign investment have also been demonstrated by Campos and Kinoshita (2003). Weak institutions may generate additional costs (e.g. corruption costs) borne by foreign investors in a host country (Wei, 2000).

Among the business environment institutions (BEI), also known as market environment institutions, there are 11 basic categories, such as: central administration institutions, regional and local development agencies, the R\&D background, associations of employers and employees, chambers and associations of producers, financial institutions, training and advisory institutions, business support institutions, networks supporting entrepreneurship and innovativeness (Dorożyński \& Urbaniak, 2011, Górzyński et al., 2006).

On the one hand, the existing business environment is a factor involved in the choice of a location for business activity. On the other hand, it can ensure a dynamic social and economic development. Business support institutions shape the investment appeal of a whole region and create its competitive edge (Wojarska et al., 2012).

Business environment institutions, in response to foreign investors' expectations, may introduce certain adaptations to the conditions over which they have considerable control; they can also take advantage of their knowhow and skills to assist potential foreign investors even in the areas which are beyond their scope of capacities. Through proper incentives and promotion of the region as a site for locating businesses, and excelling what competitive countries do in this respect, new investments are attracted (Kalinowski et al., 2007).

Building a rational and appropriate image of Poland as a country open to investment initiatives among foreign investors is an important condition that affects the inflow of foreign investment, as the FDI, to Poland. Promotion of the country should encompass different spheres: social, economic, political, cultural or as a tourist destination. In the long run, creating a positive image of Poland as a country to invest in can raise foreign investors' interest and encourage them to locate their capital. However, the continually growing competition among foreign investment recipients across the world forces countries to deploy various marketing strategies whose aim is to raise the FDI influx or at least to maintain it on a stable level.

The Polish Information and Foreign Investment Agency (the PAIiIZ) is one of the institutions which assist foreigners in making investment decisions in Poland. It encourages foreign investors to locate capital in Poland 
and guides them through all necessary administrative and legal procedures during investment projects. Regional Investor Service Centres (COI) belong to the all-Poland network of such centres, which are partner institutions of the PAIilZ. The main objective of a regional COI is to provide foreign investors with complex services on the level of a province, which means that there are 16 regional COIs in Poland. Each has been set up in collaboration with the Marshal of a given province, and the structures of the Marshal Office as well as the Regional Development Agencies are the main field for the centres' operations. Among the tasks performed by the COIs is to attract foreign investors, assist them during the implementation of investment project and to provide them with help afterwards (Lizińska, 2012).

The COI personnel works according to the standards and procedures established by the PAIiIZ, which ensure them with a certain degree of independence, while offering services to investors who contact their centre directly. Each COI office covers a whole province in which it is situated. The centres are in contact with business environment institutions and with local governments, which act for the sake of development of a given province ${ }^{1}$.

Each COI has also been assigned such tasks as: making and updating inventories of investment offers in the region, divided into greenfield and brownfield investment projects, making the inventories available to the PAIiIZ, collecting statistical data from the province within the scope determined by the PAIiIZ, collecting and updating information about public and private projects which can be executed with some contribution by foreign investors, assisting trade and investment missions to and from the province, in collaboration with the PAIiIZ (Bąk et al., 2006).

Attracting investors by business support institutions is a complex process, which sometimes fails to lead to a decision on commencing an investment project. External entrepreneurs (domestic and foreign ones) are a specific group of investors, who possess less knowledge about the conditions governing businesses in a given region. To outsiders, an investment process in an alien environment may appear more complicated and burdened with a specific risk. A question arises whether business environment institutions (in our case, the Investor Service Centres, COIs) take advantage of all tools they possess in order to attract investors to investing areas lying in their official capacity.

${ }^{1}$ http://www.paiz.gov.pl/regiony/coi (19.05.2013). 


\section{Acquisition of information about investors by COIs versus acquisition of information about investment opportunities by investors}

By searching and acquiring all information about foreign investors, investor service centres and other institutions can offer adequate help to foreign investors, which translates into more investments in the area they cover. It is essential to know what potential investors expect and what branches of industry they represent. The research has demonstrated that a COI personnel uses various sources of information. Most often, they participate in seminars, conferences and exhibitions (25\% replies), and search web pages $(21 \%)$. Other common sources of information are specialist journals and information from government institutions (each option chosen by $15 \%$ of the respondents), such as the PAIiIZ and WPHIs (Departments of Trade and Investment Promotion) (Fig. 1). These results prove that COI employees use most of the available sources of information about foreign investors. It was promising to find out that COIs are very active in their information search, and do not resort to the simplest possibilities, for example the Internet.

Figure 1. Source of information about foreign investors, acquired by COIs

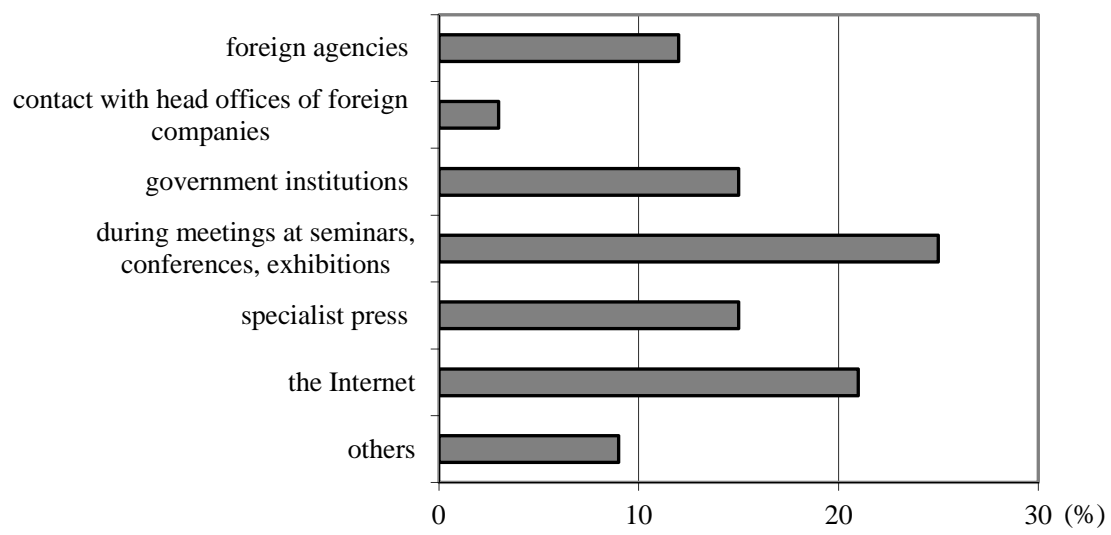

Source: the author, based on own survey research.

Another important stage in the process of attracting and assisting foreign investors is when the way in which they obtain relevant data is diagnosed and evaluated. This information helps to develop a strategy for an improved system of foreign investment acquisition. Of special importance will be the knowledge of channels for the transfer of information about the conditions 
governing business activity in Poland and subjects which make such information available. All of the questioned representatives of COIs reported that foreign investors contacted their offices having previously found relevant information about chosen investment locations. Also, all the respondents said that some investors had been referred to COIs by other institutions, most often the PAIiIZ and Departments of Trade and Investment Promotion (Fig. 2).

Figure 2. Sources of information about investment areas used by foreign investors according to COI officials

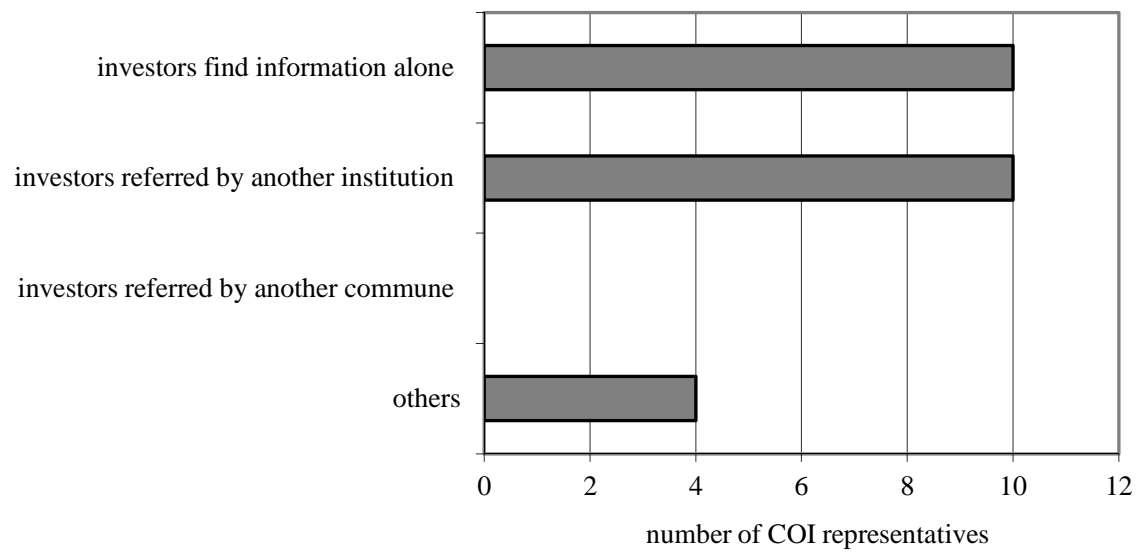

Source: the author, based on own survey research.

Another source of information used by foreign investors applying to COIs for assistance consisted of other investors already active in a given region and managers of special economic zones. According to respondents, foreign investors were not referred to COIs by authorities of communes, which may be due to the fact that it is COI officials who send investors to particular communes and provide them with all necessary information. Another reason can be that authorities of communes instruct investors to contact managers of special economic zones.

\section{Diagnosis and assessment of areas of collaboration between investor service centres (COIs) and other institutions}

Promotion of investment areas by COIs in collaboration with other institutions ensures reaching a broader circle of potential foreign investors, which 
in turn translates into a higher number of commenced investment projects in Poland. The current study has demonstrated that nearly all (90\%) representatives of COIs cooperated with special economic zones or with local administration officials. The respondents most often collaborated with special economic zones (22\% replies) and with local authorities (20\%). Some of the respondents (15\%) also collaborated with Marshal Offices and other institutions (18\%), such as the PAIiIZ, WPHIs, job offices, regional commerce chambers, industrial and technology parks, developers, and independent companies which make assessment analyses of the investment attractiveness of particular regions. The questioned representatives of COI also contacted regional development agencies (10\%), district governments (8\%), other investor service centres (5\%) and banks (3\%). However, none of the respondents said they collaborated with the authorities of provinces (Fig. 3).

Figure 3. Collaboration of COIs with offices and other institutions

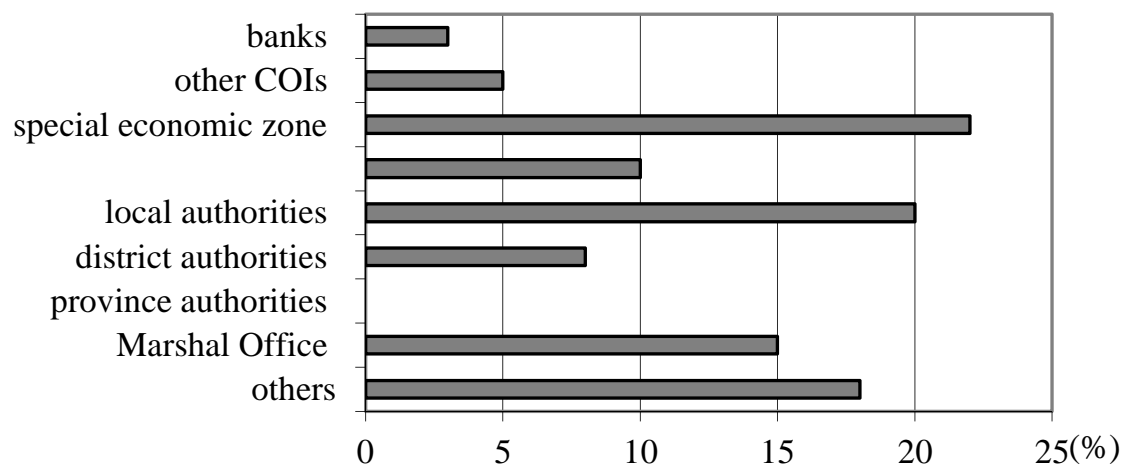

Source: the author, based on own survey research.

Collaboration with other COIs has not been very common mainly because each COI focuses on matters related to their province and investment projects located therein. However, whenever a COI is unable to suggest a suitable area for an investment project a foreign business entity wishes to implement, it would be recommendable to refer such an investor to another COI, as part of collaboration between the centres. This would mean that each centre should keep up to date with investment offers available in other provinces and that all centres might want to develop a model of cooperation. In practice, it is not rare to hear opinions that particular regional institutions mainly compete with one another. It is worth considering whether collaboration with individual institutions and offices is adequate and if it should not be broadened to encompass other institutions with the aim of expanding the target of campaigns promoting available development areas. 
Another issue raised in the completed survey was the identification of areas of cooperation between COIs and offices as well as other institutions. Many respondents $(21 \%)$ prepared professional investment offers in collaboration with other institutions, and cooperated with them while promoting investment areas. The shared coordination of activities by several institutions including COIs was the answer chosen by $17 \%$ respondents. Another task performed in collaboration with others, although less often, was to train an employee of an office or institution who would be responsible for contact with the local COI and assisting foreign investors, and to prepare joint training sessions (14\% each reply) (Fig. 4).

Figure 4. Activities pursued by COIs in cooperation with other institutions, in order to acquire foreign investments

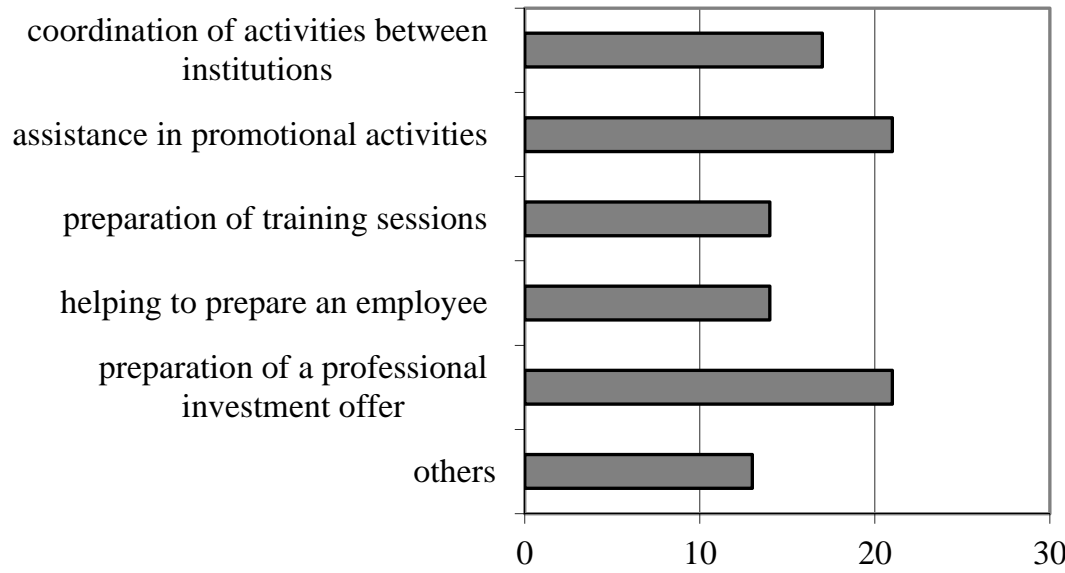

Source: the author, based on own survey research.

Undoubtedly, the replies given by COI employees suggest that they actively cooperate with other institutions in order to attract foreign investors. As the survey research shows, they undertake various activities to reach this aim, most of which demand a high degree of engagement. For example, COI officials participate in conferences, including international ones, which increase chances of attracting foreign capital.

\section{Activities undertaken by investor service centres while acquiring investors}

The author's survey research confirmed that all the questioned representatives of investor service offices were making attempts to attract foreign 
investors, both offering different forms of assistance to investors and preparing investment offers and areas. COI officials also collaborated with other institutions to promote investment areas, and themselves searched for information regarding potential foreign investors. It is obvious that the promotional work done by COIs contributes to the acquisition of foreign investments in Poland and attracts foreign investors, and this conclusion is verified by dozens of foreign investors who contact COIs each year (Fig. $5)$.

Figure 5. Importance of activities pursued by COIs in the process of foreign investment acquisition ( 3 - most important, 0 - the activity does not apply to the given stage)

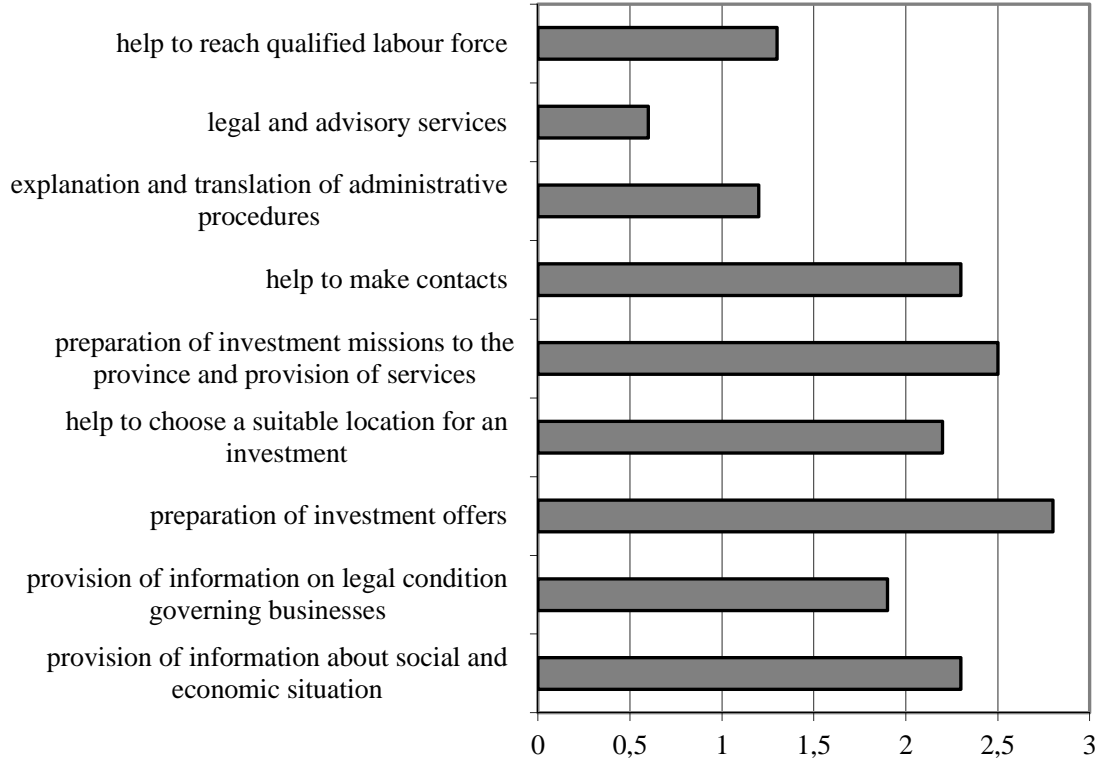

Source: the author, based on own survey research.

To a large extent, the final effect, such as the acquisition of foreign capital, depends on how successfully COIs reach potential investors with their offer, which is achieved through various forms of promotion. When evaluating the work done by COIs employees in order to promote their region among foreign investors, the following methods stand out: promotion of available investment areas on web pages and presentations during exhibitions, promotional events and trade fairs. In turn, advertisements in printed materials addressed to foreign investors were chosen as a promotional activity by 7 representatives of COIs, while 6 said they sent offers directly to companies and embassies, or made direct contact with representatives of 
foreign companies (Fig. 6). Most often COI employees promoted available investment sites themselves rather than delegate this task to agencies. Promotional campaigns run by COIs are on a high, professional level, which certainly stimulates a higher inflow of foreign investments to individual regions.

Figure 6. Promotional activities pursued by COIs

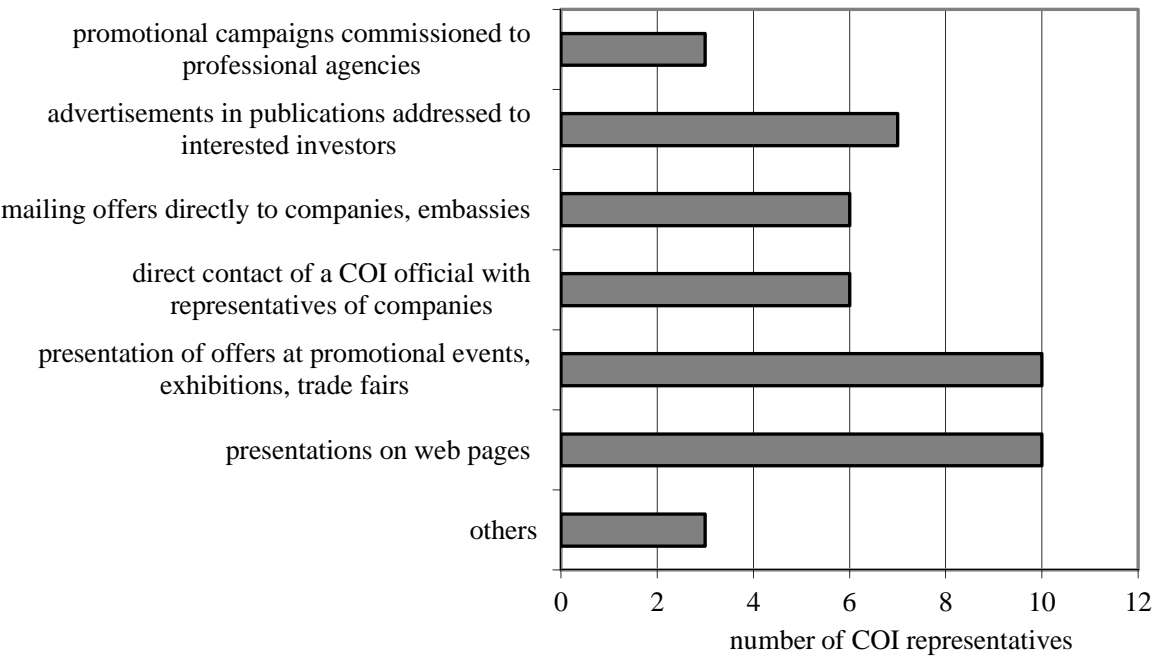

Source: the author, based on own survey research.

Investment offers sent to other institutions by COIs in order to promote investment areas within their capacity are an important element in the acquisition of foreign investors, because they are more likely to be noticed by larger groups of entrepreneurs. The survey has shown that 9 of the questioned COI respondents cooperated with other institutions and mailed their investment portfolios in order to promote investment areas (Fig. 7).

Most such offers $(26 \%)$ were sent to the PAIiIZ, WPHIs, science and technology parks, foreign chambers associating entrepreneurs. Quite a few respondents also sent their offers to special economic zones and marshal offices (17\% each). Fewer offers were sent to regional development agencies and to local governments and authorities (1 COI each). 
Figure 7. Sending investment offers by COIs to other institutions

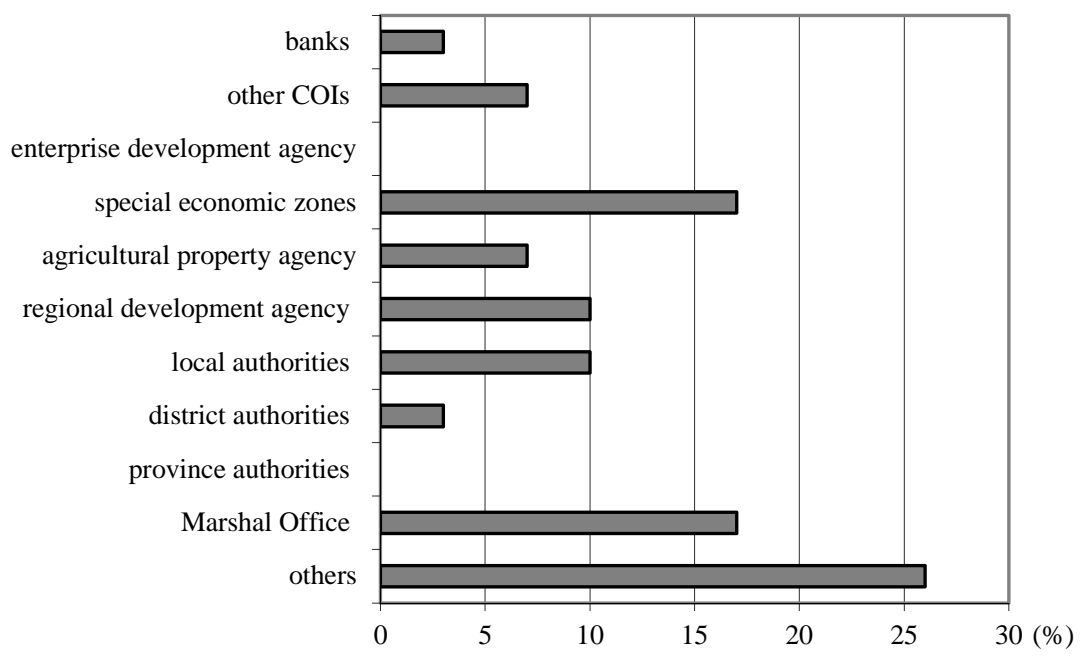

Source: the author, based on own survey research.

\section{Conclusions}

The results of the survey conducted among COI officials justify the claim that these institutions participate in the acquisition of investors, which is a consequence of the tasks they are assigned to perform. Certain differences between COIs in the scope of pursued activities may appear because of different strategies that individual centres have adapted as well as the specific character of a region in which each centre functions. While all the centres operate in compliance with the standards worked out by the PAIiIZ and are regional partners of the agency, regional authorities have been given freedom to create investor service centres in specific institutional structures. The specific character of individual centres may therefore be connected with the general level of the activity demonstrated by institutions to which COIs have been attached.

An interesting finding emerging from the research is that while COIs actively search for all kind of information about foreign investors, they conclude that investors who contact them have most often found out about certain business opportunities by themselves or else have been referred by another institution. How can, therefore, the effectiveness of COIs be assessed in terms of the work they do? This is a serious problem especially in the light of the fact that very few COI respondents affirmed that they cooperated with other institutions. And when being established, COIs were intended to create a countrywide network of regional organizations reporting to the main institution responsible for acquisition of foreign investors such 
as the PAIiIZ. If they were to make a network, then one would expect a greater degree of collaboration between all centres, and would hope that they should perceive the process of attracting foreign investors from the point of view of the whole country, not just one region.

The activity of each COI, primarily shaped by the needs and expectations of the broadly understood region in which it operates, may even lead to the loss of an investor. The low attractiveness of investment areas in some regions compounded by the inadequate cooperation with other COIs restricts the range of potential investment opportunities that can be offered to investors. On the other hand, COI officials themselves highlighted the importance of having a rich portfolio of business opportunities.

In order to improve the efficiency of regional investor service centres all across Poland, which can be defined by the number and value of foreign investments undertaken in our country, we should strive towards building such a relationships between these institutions that in the management studies are called coopetition, i.e. while competing regional COIs simultaneously cooperate with one another.

The above considerations are based on a questionnaire completed by COI officials. The current research could be expanded and involve foreign investors. Knowing their opinion on the acquisition of foreign capital and assistance offered to foreign entrepreneurs in Poland in the context of support institutions (including COIs) should enable us to achieve a more precise diagnosis and evaluation of the whole process.

\section{References}

Acemoglu, D., Johnson, S., \& Robinson J. A. (2005). Institutions As A Fundamental Cause Of Long-Run Growth. In P. Aghion \& S. N. Durlauf (Eds.). Handbook of Economic Growth. Vol. I A. http://dx.doi.org/10.1016/S15740684(05)01006-3.

Bąk, J., Bąk, M., \& La Croix, D. (2006). Promocja gminy, miasta i regionu w kontekście integracji europejskiej. Techniki przygotowywania materiałów promocyjnych i ofert inwestycyjnych. Zasady obstugi inwestorów. Warszawa: Twigger.

Balcerzak, A., (2011). Integracja instytucjonalna w krajach Unii Europejskiej. Propozycja pomiaru. Ekonomia i Prawo, 7(1).

Balcerzak, A., Rogalska, E., (2010). Zawodność instytucjonalna Państwa w zakresie stwarzania warunków dla przedsiębiorczości w krajach Europy ŚrodkowoWschodniej. Ekonomia i Prawo, 6(1).

Campos, N. F., \& Kinoshita, Y. (2003). Why Does FDI Go Where it Goes? New Evidence from the Transition Economies. IMF Working Paper Vol. 3, No. 228. 
Dorożyński, T., \& Urbaniak, W. (2011). Rola instytucji otoczenia biznesu we wspieraniu inwestorów zagranicznych w województwie łódzkim. In: J. Świerkocki (Ed.). Rola bezpośrednich inwestycji zagranicznych $w$ ksztattowaniu aktualnego i przysztego profilu gospodarczego województwa tódzkiego. Łódź: Łódzkie Towarzystwo Naukowe.

Geldner, M. (1986). Przyczynek do teorii zagranicznych inwestycji bezpośrednich. Warszawa: Monografie i Opracowania 193.

Górzyński, M., Pander, W., \& Koć, P. (2006). Tworzenie związków kooperacyjnych między MSP oraz MSP $i$ instytucjami otoczenia biznesu. Warszawa: PARP.

http://www.paiz.gov.pl/regiony/coi (19.05.2013).

Kalinowski, T., Hildebrandt, A., Nowicki, M., Susmarski, P., \& Tarkowski, M. (2007). Atrakcyjność inwestycyjna województw i podregionów Polski. Gdańsk: Instytut Badań nad Gospodarką Rynkową.

Lissowska, M. (2004). Instytucjonalne wymiary procesu transformacji w Polsce. Warszawa: Wyd. SGH.

Lizińska, W. (2012). Klimat inwestycji jako czynnik bezpośrednich inwestycji zagranicznych $w$ Polsce - studium na poziomie układów terytorialnych. Olsztyn: UWM w Olsztynie.

Miłaszewicz, D. (2011). Jakość instytucji a wzrost gospodarczy. Studia i Prace Wydziału Nauk Ekonomicznych $i$ Zarzadzania, Wydawnictwo Naukowe Uniwersytetu Szczecińskiego, 19.

Rudolf, S. (2012). Nowa ekonomia instytucjonalna lekarstwem na kryzys In: S. Rudolf (Ed.). Nowa ekonomia instytucjonalna: teoria $i$ zastosowania. Kielce: Wydawnictwo Wyższej Szkoły Ekonomii i Prawa, Kieleckie Towarzystwo Edukacji Ekonomicznej.

Rymarczyk, J. (1996). Internacjonalizacja i globalizacja przedsiębiorstwa. Warszawa: Polskie Wydawnictwo Ekonomiczne.

Wei, S. J. (2000). How taxing is corruption on international investors?. Review of Economic and Statistic. 82(1). http://dx.doi.org/10.1162/003465300558533.

Williamson, O. (1998). Ekonomiczne instytucje kapitalizmu. Firmy, rynki, relacje kontraktowe. Warszawa: Wydawnictwo Naukowe PWN.

Wojarska, M., Marks-Bielska, R., \& Babuchowska, K. (2012). Innowacyjność i konkurencyjność IOB jako stymulanta rozwoju woj. warmińsko-mazurskiego. Ekonomia, Wydawnictwo UE we Wrocławiu, 2(19).

Zalesko, M. (2014). Instytucje w procesie rozwoju gospodarczego In: S. Rudolf (Ed.). Nowa ekonomia instytucjonalna wobec wspótczesnych problemów gospodarczych. Kielce: Wydawnictwo Wyższej Szkoły Ekonomii, Prawa i Nauk Medycznych: Kieleckie Towarzystwo Edukacji Ekonomicznej. 